\title{
Antibacterial activity of ethyl acetate fraction from methanolic extracts of ant-plant tubers towards Streptococcus sanguis ATCC 10566
}

\author{
Fajar Fatriadi*, Dikdik Kurnia**, Mieke Hemiawati Satari*** \\ *Department of Conservative Dentistry, Faculty of Dentistry, Universitas Padjadjaran, Indonesia \\ ** Department of Chemistry, Faculty of Mathematics and Natural Sciences, Universitas Padjadjaran, \\ Indonesia \\ *** Department of Oral Biology, Faculty of Dentistry, Universitas Padjadjaran, Indonesia
}

\section{ABSTRACT}

Introduction: Streptococcus sanguis is an initial cause of dental plaque formation which is the initial cause of caries. One of the preventive treatments can be done by using the mouthwash containing antibacterial substances. Along time, natural remedies are proven to be having more antibacterial properties. Antplant (Myrmecodia pendens Merr. \& Perry) tubers are types of epiphytic plant that grows in many parts of Papua, with many health benefits, and are known to contain flavonoids, tannins, and tocopherols. This study was aimed to determine the antibacterial activity of ethyl acetate fraction from methanolic extracts of ant-plant tubers on the growth of Streptococcus sanguis ATCC 10566. Methods: The ant-plant tubers were extracted with soxhletation method using the methanol solvent. The fractionation was then performed using ethyl acetate to obtain the ethyl acetate fraction. Result: The phytochemical test showed that the ethyl acetate fraction of the ant-plant contained phenolics, tannins, flavonoids, and terpenoids. The bacterial test in this study was using the microdilution method using the ELISA Reader by measuring the Minimum Inhibitory Concentration (MIC) of ethyl acetate fraction of ant-plant tubers towards Streptococcus sanguis with positive control was using the chlorhexidine gluconate as the golden standard medication. The ethyl acetate fraction of ant-plant tuber had an antibacterial effect towards Streptococcus sanguis in the MIC of $31.25 \mathrm{ppm}$, while chlorhexidine gluconate was $0.49 \mathrm{ppm}$. Conclusion: The ethyl acetate fraction of ant-plant had a lower antibacterial activity compared to chlorhexidine gluconate on the growth of Streptococcus sanguis ATCC 10566.

Keywords: Ant-plant tubers, Myrmecodia pendens Merr. \& Perry, antibacterial activity, Streptococcus sanguis ATCC 10566

P-ISSN 1979-0201, e-ISSN 2549-6212 Available from:http://jurnal.unpad.ac.id/pjd/article/view/20002 DOI: http://dx.doi.org/10.24198/pjd.vol30no3.20002

Submission: Feb 17, 2017; Reviewed: Jan 10, 2018; Resubmit for review: Jul 3, 2018; Accepted: Oct 25, 2018; Published online: Nov 30, 2018:

Corresponding author: Fajar Fatriadi, Department of Conservative Faculty of Dentistry Universitas Padjadjaran, indonesia Jalan Sekeloa Selatan I, Bandung, Indonesia 40132. Phone: +628122368138; Email: fajar.fatriadi@fkg.unpad.ac.id. 


\section{INTRODUCTION}

Dental caries is one of the most common human diseases. Data from the Ministry of Health of the Republic of Indonesia showed that caries prevalence in Indonesia reaches $60-80 \%$ of the population, and ranks sixth as the most common disease. ${ }^{1}$ The process of caries begins with the habit of not brushing your teeth and causing an unhealthy and unclean mouth, including the formation of dental plaque. Dental plaque is a soft deposit of bacterial mass that attaches to the surface of the hard tissue of teeth that are not properly cleaned, which contains living or dead microorganisms and their products. ${ }^{2}$

Streptococcus sanguis is the main bacteria that causes the formation of dental plaque. ${ }^{3,4}$ Other precautions to avoid caries besides brushing teeth are good and right, one of which is the use of mouthwash that contains antibacterial substances, namely chlorhexidine gluconate.

Along time, the use of drugs from herbal plants is increasing. Much research has been done on natural plants that have antibacterial properties. According to the World Health Organization, plants are a potential source of finding new drugs. ${ }^{5}$ In terms of safety, drugs from plants can be said to be quite safe when compared to synthetic drugs. This natural product can be a preferred alternative in drug use because it has the ability of high antimicrobial activity, is biocompatible, and has anti-inflammatory and antioxidant effects. One of the plants that are useful as a medicinal plant is the ant-plant tuber (Myrmecodia pendens Merr \& Perry). ${ }^{6}$

Ant-plant is a type of epiphytic plant that grows attached to other plants and has long been used as a drug in the Papua region to maintain and treat health problems. Empirically, the ant nest plant can cure a variety of serious diseases such as tumours, cancer, heart disease, haemorrhoids, tuberculosis, rheumatism, gout disorders, strokes, stomach ulcers and kidney and prostate dysfunction. Also, boiled extracts of ant-plants are also proven to be able to facilitate breast milk (ASI), increase sexual desire for men and women and are useful for facilitating menstruation, as well as overcoming vaginal discharge. ${ }^{6}$

Ant-plant tubers are known to contain flavonoids, tannins and tocopherols. In many cases, flavonoids can play a direct role as antibiotics by disrupting the function of bacterial microorganisms or viruses. ${ }^{6}$ Flavonoids and tannins are included in the polyphenol group, where polyphenols are active compounds that have been shown to function as antiseptics against bacteria. ${ }^{7-9}$ Many cases have reported, flavonoids can play a direct role as antibacterial by disrupting the function of bacterial microorganisms. Flavonoids and tannins are included in the group of polyphenols whose main component is phenol, so that the mechanism of action is to denaturate proteins of bacterial cell walls, especially the outer wall, whose main ingredient is nanoprotein, causing damage to the membrane. Similar to detergent because of the polarity of the hydroxyl group, so that it inhibits the formation of amino acids. Furthermore, the integrity of cell membranes cannot be maintained, and cell metabolism is disrupted so that eventually bacterial cells will be lysis.

The group of compounds of active substances contained in the ant nest tubers can be extracted by a solvent, for example, methanol. The phytochemical test of methanol extract of ant nest tubers was known that the extract contained compounds including alkaloids, saponins, flavonoids, and terpenoids. ${ }^{6}$ The purpose of this study was to determine the presence or absence of antibacterial activity in the ethyl acetate fraction of methanol extract of ant-plant tubers (Myrmecodia pendens) against the growth of Streptococcus sanguis compared to chlorhexidine gluconate.

\section{METHODS}

The subject of this study was the antibacterial activity of ethyl acetate fraction from methanolic extracts of ant-plant tubers towards the growth of Streptococcus sanguis in liquid media. The sample used in this study was ethyl acetate fraction from methanolic extracts of ant-plant tubers. The bacteria used in this study was Streptococcus sanguis ATCC 10566.

The sampling technique used in retrieving tubers of ant-plants was a simple random, assuming that each element in the population has the same opportunity to be chosen as a sample. The variables in this study were the antibacterial activity of ethyl acetate fraction from methanolic extracts of ant-plant tubers and chlorhexidine 
Table 1. Phytochemical test results of ethyl acetate fraction from methanolic extracts of ant-plant tubers

\begin{tabular}{lllllllll}
\hline & & & Alkaloid & Saponin & Phenolic & Flavonoid & Terpenoid & Tannin \\
\hline $\begin{array}{l}\text { Ethyl acetate fraction from } \\
\text { extracts of ant-plant tubers }\end{array}$ & methanolic & - & + & +++ & +++ & & +++ & +++ \\
\hline
\end{tabular}

Notes: (-) : Not contained (+) : Contained less (+++) : Contained much

Table 2. MIC value of ethyl acetate fraction from methanolic extracts of ant-plant tubers and chlorhexidine gluconate towards the growth of Streptococcus sanguis ATCC 10566

\begin{tabular}{|c|c|c|}
\hline No & Sample & MIC value $(\mathrm{ppm})$ \\
\hline 1 & Ethyl acetate fraction from methanolic extracts of ant-plant tubers & 31.25 \\
\hline 2 & Chlorhexidine gluconate & 0.49 \\
\hline
\end{tabular}

gluconate on the growth of Streptococcus sanguis ATCC 10566. The method of data collection carried out was a true experiment. The type of data used is quantitative, and data was collected by measuring or calculating using a tool such as Elisa Reader to estimate the minimum inhibitory concentration (MIC) value of ethyl acetate fraction from methanolic extracts of ant-plant tubers and chlorhexidine gluconate on the growth of Streptococcus sanguis ATCC 10566.

The materials and tools used in this study were ant nest tubers, Streptococcus sanguis ATCC 10566, liquid media, microplate and Elisa Reader. The method used to extract the ant-plant tubers was soxhletation using methanol solvent, then fractionation using ethyl acetate solvents so that the ethyl acetate fraction from methanolic extracts of ant-plant tubers was produced.

Phytochemical tests were carried out to determine the content of groups of compounds contained in ethyl acetate fraction from methanolic extracts of ant-plant tubers. Phytochemical testing includes testing of alkaloids, saponins, phenolics, flavonoids, terpenoids and tannins. The antibacterial activity test (MIC) procedure was carried out using a microdilution method, which was then measured using a tool such as ELISA Reader which was seen from its optical density value. The results obtained were assessed in ppm concentration.

\section{RESULT}

The phytochemical test on ethyl acetate fraction from methanolic extracts of ant-plant tubers gave positive results, including containing groups of saponin compounds, phenolics, flavonoids, terpenoids and tannins (Table 1 ). The MIC test results showed that ethyl acetate fraction from methanolic extracts of ant-plant tubers had MIC values at a concentration of $31.25 \mathrm{ppm}$ while chlorhexidine gluconate at a concentration of 0.49 ppm (Table 2).

\section{DISCUSSION}

The MIC value of the ethyl acetate fraction of ant-plant tubers was obtained at the same ppm concentration as it's methanolic extract, which was $31.25 \mathrm{ppm} .^{7}$ The same results were suspected because the phytochemical test between the ethyl acetate fraction and methanol extract of antplant tubers had a high content group of similar compounds, so that the MIC results were possible at the same concentration (Table 1). ${ }^{7}$

The difference obtained from the MIC value of the ethyl acetate fraction of ant-plant tubers compared to chlorhexidine gluconate was occurred due to differences in the mechanism of action of the two samples. Chlorhexidine gluconate is still one of the golden standards of mouthwash while the use of ant-plant tubers is still in the fractionation stage. The mechanism of action of chlorhexidine causes changes in the surface structure of bacteria which ultimately causes the rupture of the bacterial cytoplasmic membrane. Meanwhile, ethyl acetate fraction contains alkaloids, saponins, phenolics, tannins and terpenoids which act as antibacterial. The mechanism of action of an alkaloid as an antibacterial is thought to be by disrupting the constituent components of peptidoglycan on the bacterial cell wall so that the cell wall layer is not fully formed and causes cell death. ${ }^{8-10}$ Flavonoid 
compounds have a working mechanism that causes damage to cell wall permeability bacteria that can damage bacterial cell membranes and are followed by the release of intracellular compounds thus able to inhibit bacterial motility. ${ }^{8-10}$

Several studies have shown that terpenoids can inhibit bacterial growth by interfering with the process of forming membranes and/or cell walls, membranes or cell walls not formed or formed but imperfect. ${ }^{11}$ Saponins work by damaging the cytoplasmic membrane by reducing surface tension resulting in increased cell permeability and leakage resulting in intracellular compounds coming out. ${ }^{12}$ The mechanism of action of phenolic as an antibacterial is poisoning protoplasm, damaging and penetrating walls and depositing bacterial cell proteins. Large molecular phenolic compounds are capable of activating essential enzymes in bacterial cells even in very low concentrations. Phenol can cause damage to bacterial cells, denaturing proteins, activating enzymes and causing cell leakage. The mechanism of action of the tannin as an antibacterial is to inhibit the reverse transcriptase and DNA topoisomerase enzymes so that the DNA transcription process is disrupted and new bacterial cells cannot be formed. ${ }^{12}$

\section{CONCLUSION}

Based on the results of this research and discussion that previously done, it can be concluded that the ethyl acetate fraction of ant-plant had a lower antibacterial activity compared to chlorhexidine gluconate on the growth of Streptococcus sanguis ATCC 10566.

\section{REFERENCES}

1. Berita Satu [homepage on internet]. Jakarta: 2011. Karies Gigi Masalah Kesehatan Serius di Indonesia. [cited 2012 Dec]; [about 9 screens]. Available from: http://www.beritasatu. com/kesehatan/14088-karies-gigi-masalahkesehatan-serius-di-indonesia.html.

2. Samaranayake L. Essential Microbiology for Dentistry. $4^{\text {th }}$ ed. London: Churchill
Livingstone; 2012. P. 95-100, 207-21.

3. Bagg J, Macfarlane TW, Poxton IR, Smith AJ. Essential Microbiology for Dental Student. $2^{\text {nd }}$ ed. Oxford: Oxford University Press; 2006.

4. Yamaguchi M, Terao Y, Ogawa T, Takahashi T, Hamada S, Kawabata S. Role of Streptococcus sanguinis sortase A in bacterial colonization. Microbes Infect. 2006;8(12-13):2791-6. DOI: 10.1016/j.micinf.2006.08.010.

5. Pujar M, Makandar S. Herbal Usage In Endodontics A Review. Int J Contemp Dent. 2011;2(1):34-7.

6. Subroto MA, Saputro H. Gempur penyakit dengan sarang semut. $2^{\text {nd }}$ ed. Jakarta: Penebar Swadaya; 2006.

7. Fatriadi F, Kurnia D, Satari MH. Perbedaan aktivitas antibakteri dari ekstrak metanol umbi sarang semut (Myrmecodia pendens Merr. \& Perry) dibandingkan dengan klorheksidin glukonat dan povidone iodine terhadap Streptococcus sanguis ATCC 10566. Proceedings of Bandung Dentistry 2016; 2016 May 20-21; Bandung, Indonesia. Bandung: Indonesian Dental Association; 2016. p. 103-8.

8. Nogrady T, Weaver DF. Medical Chemistry: A Molecular and Biochemical Approach $3^{\text {rd }}$ ed. Oxford: Oxford University Press; 2005.

9. Akiyama H, Fujii K, Yamasaki O, Oono T, Iwatsuki K. Antibacterial action of several tannins against Staphylococcus aureus. J Antimicrob Chemother. 2001;48(4):487-91. DOI: $10.1093 / \mathrm{jac} / 48.4 .487$.

10. Nijveldt RJ, van Nood E, van Hoorn DE, Boelens PG, van Norren K, van Leeuwen PA. Flavonoids: a review of probable mechanisms of action and potential application. Am J Clin Nutr. 2001;74(4):418-25. DOI: 10.1093/ ajen/74.4.418.

11. Ajizah A. Sensitivitas Salmonella typhimurium terhadap Ekstrak Daun Psidium Guajava L. Bioscientiae. 2004;1(1):31-8.

12. El-Nakeeb MA, Abou-Shleib HM, Khalil AM, Omar HG, El-Halfawy OM. Membrane permeability alteration of some bacterial clinical isolates by selected antihistaminics. Braz J Microbiol. 2011;42(3):992-1000. DOI: 10.1590/S1517-838220110003000019. 